\title{
The foggaras of Bouda (Algeria): from drought to flood
}

\author{
Youcef Boutadara $^{1} \cdot$ Boualem Remini $^{2} \cdot$ Saida Benmamar ${ }^{1}$
}

Received: 24 May 2018 / Accepted: 12 September 2018 / Published online: 19 September 2018

(c) The Author(s) 2018

\begin{abstract}
Based on investigations and flow gauges that we conducted in all the foggaras of the Bouda Oasis during the period: 20152018 , this article examines an original hydraulic phenomenon that occurred recently in the oasis of Bouda in the wilaya of Adrar (Algeria). The exploitation of the boreholes made during the 1980s in the export field of foggaras caused a drying of foggaras water. However, in 2015, the remoteness of the well field and the supply of drinking water by the water resources services led to an increase in foggara flows. At first, it was good news for farmers, but over time the phenomenon became worrying for the population, since the flow has not yet stabilized. The phenomenon is starting to grow; sebkhas and palm groves are today flooded by the surplus of waters of foggaras.
\end{abstract}

Keywords Foggara $\cdot$ Bouda $\cdot$ Folding $\cdot$ Tablecloth $\cdot$ Flood $\cdot$ Rise of the tablecloth

\section{Introduction}

For more than 10 centuries, the foggara has played a key role in the development and stabilization of oases in the regions of Touat, Gourara and Tidikelt. Based on a slightly inclined underground gallery, the water of the aquifer flows slowly over a length of about $10 \mathrm{~km}$ to reach the gardens located at a lower dimension than the piezometric line of the aquifer (250 m) (Remini 2017; Remini and Achour 2016; Remini et al. 2011, 2014a, b). Today, this ancestral hydraulic system still operates despite strong competition from other capture techniques such as motor pumps and drilling. If the origin of the foggara still presents doubts, the works of Goblot (1963, 1979) gave some details, since the foggara is of Persian origin (ancient Iran) and known under the name of Qanat. Thanks to its success, foggara has developed in more than 50 arid and semiarid countries (Remini et al. 2014a). Can

Boualem Remini

remini1961@gmail.com

Youcef Boutadara

bouta_youcef@yahoo.fr

Saida Benmamar

benmamar@yahoo.fr

1 Department of Hydraulics, National Polytechnic School of Algiers, 16000 Algiers, Algeria

2 Department of Water Sciences and Environment, Faculty of Technology, University of Blida, 9000 Blida, Algeria the foggara be downgraded to the detriment of new catchment techniques, since the installation of boreholes on the outskirts of the foggaras wellfield has caused the water table to be pulled down? Such a situation has led to a decrease in the flow of some foggaras and others have been completely dried up. Several cases have been reported in Gourara (Remini et al. 2011). For example, the foggara of El Meghier one of the largest foggara of Gourara saw its flow decreases from $50 \mathrm{~L} / \mathrm{s}$ in 1970 to $3 \mathrm{~L} / \mathrm{s}$ in 2007 following the problem of pumping in the fields of foggaras (Remini and Achour 2008a). In addition to the problem of inheritance (Remini and Kechad 2017), the contribution of new techniques in the oases remains a thorny problem whose consequences are the abandonment of a thousand-year-old hydraulic system. So can we find a compromise between the two techniques (old and modern), a kind of cohabitation? Moreover, the phenomenon of rising water table caused in recent months in the oasis of Bouda is only one answer to this question. It is through this contribution that we try to provide some information on the effect of the drilling installed in the foggaras catchment area of the oasis of Bouda. 
Fig. 1 Geographical location of the study area. (own elaboration)
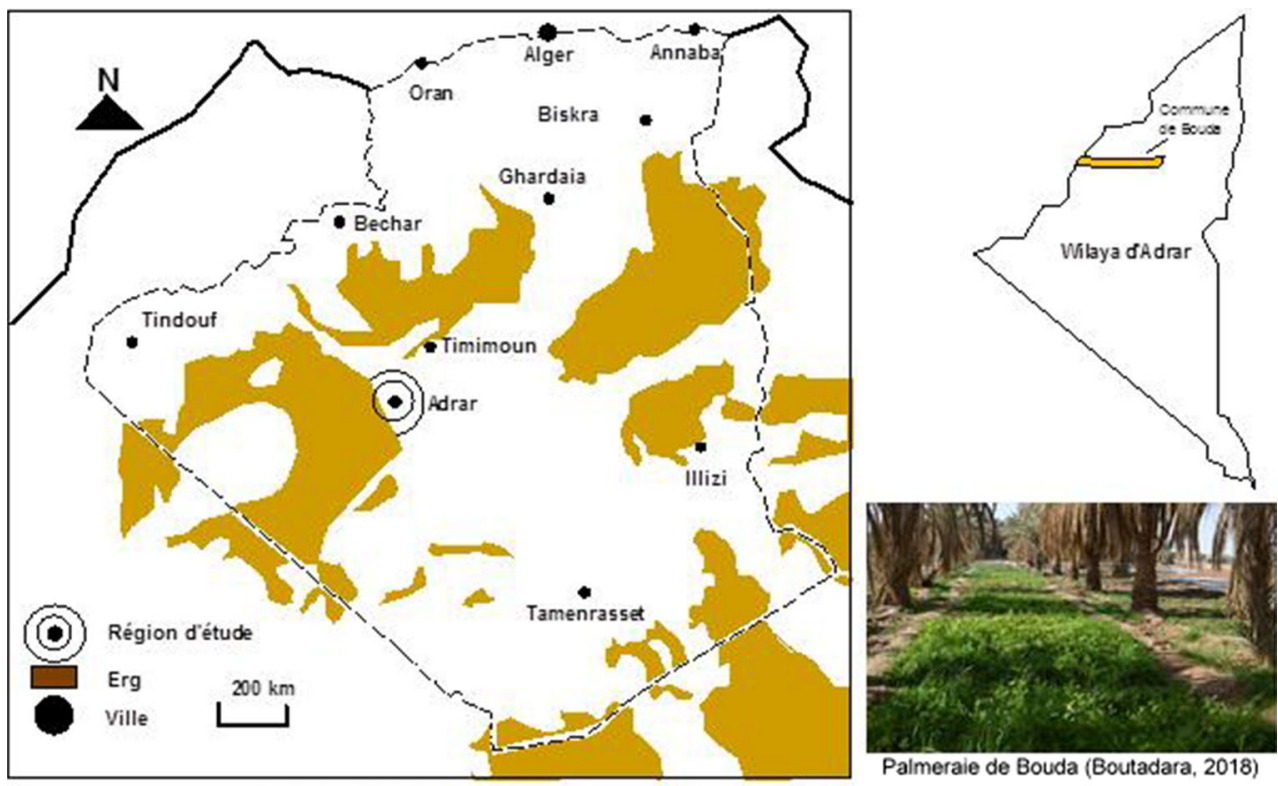

\section{Region of study and methodology of work}

\section{Location and characteristics of the region}

Located $1035 \mathrm{~km}$ as the crow flies southwest of Algiers, Adrar, a large wilaya of southern Algeria, occupies an area of $424,948 \mathrm{~km}^{2}$ or $10 \%$ of the total area of the largest hot desert on the planet (Fig. 1). Adrar is a hyper-arid region known by this hot weather during the summer period and the scarcity of precipitation during the winter period. However, the subsoil of Adrar contains a part of the aquifer of Intercalary Continental, one of the greatest aquifer on the planet. Called Albian foggaras, the foggaras of Touat exploit the waters of the Intercalary Continental aquifer (Remini and Achour 2016). Bouda a beautiful oasis known by these thirty foggaras is located $15 \mathrm{~km}$ northwest of Adrar.

\section{Data used and surveys}

To better understand the influence of the drilling on the drawdown of the water table and the drying of the foggaras located near these boreholes, we made several outings in the oases of Bouda during the period: 2015-2018. Investigations and surveys have been conducted among farmers and the local population to get information on the phenomenon of the rise of the water table since May 2017. This is how a rigorous monitoring of the evolution of flows of foggaras of Bouda was operated by gauging and flow measurements at the kasriates and the seguias (Figs. 2, 3, 4, 5).

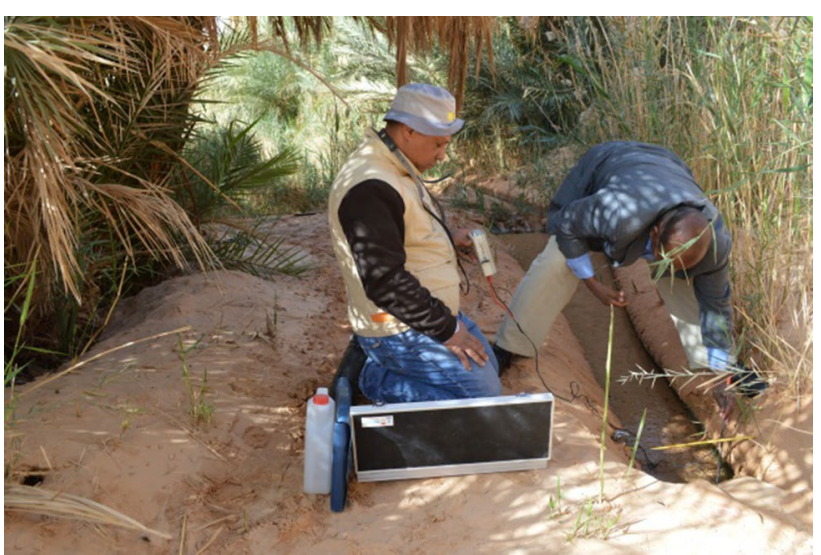

Fig. 2 February 4, 2018, gauging the foggaras El Hadj Amar Kebir at the kasria level. (photo. Authors 2018)

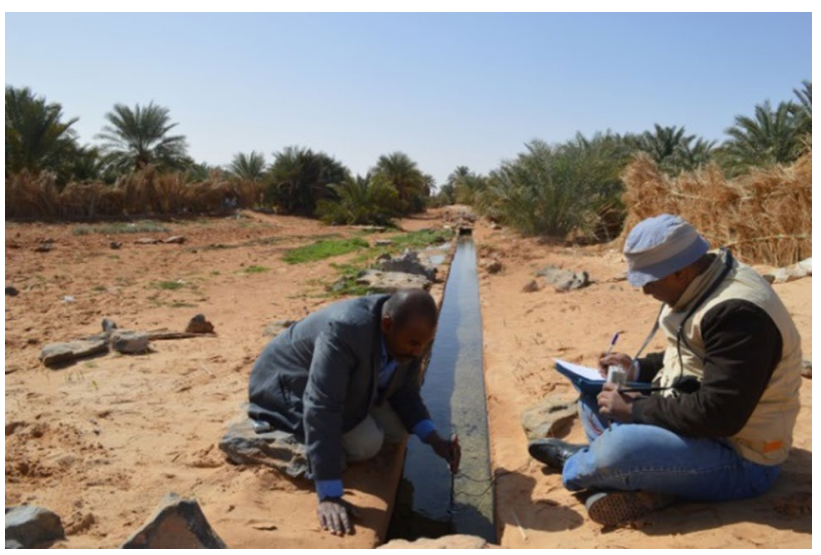

Fig. 3 February 07, 2018, gauging of the foggara of Bouzid at the level of the main canal. (photo. Authors 2018) 


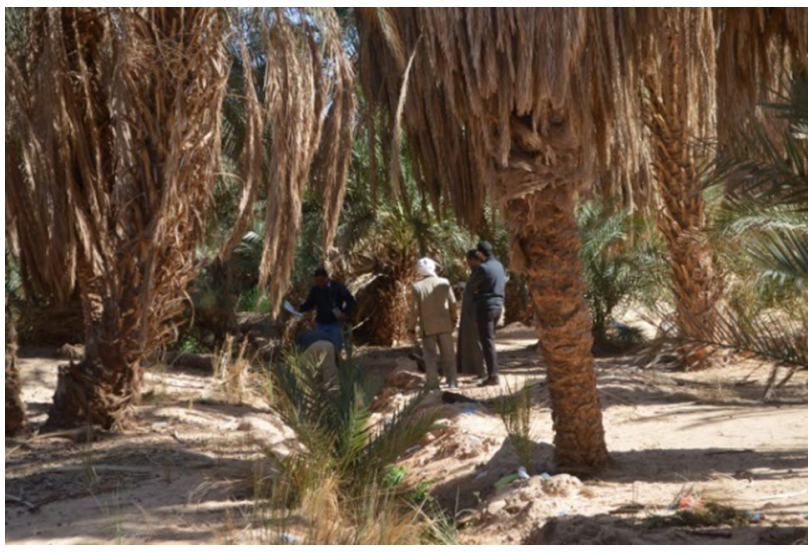

Fig. 4 January 22, 2018, investigations of the seguias of the foggara of Tamllal. (photo. Authors 2018)

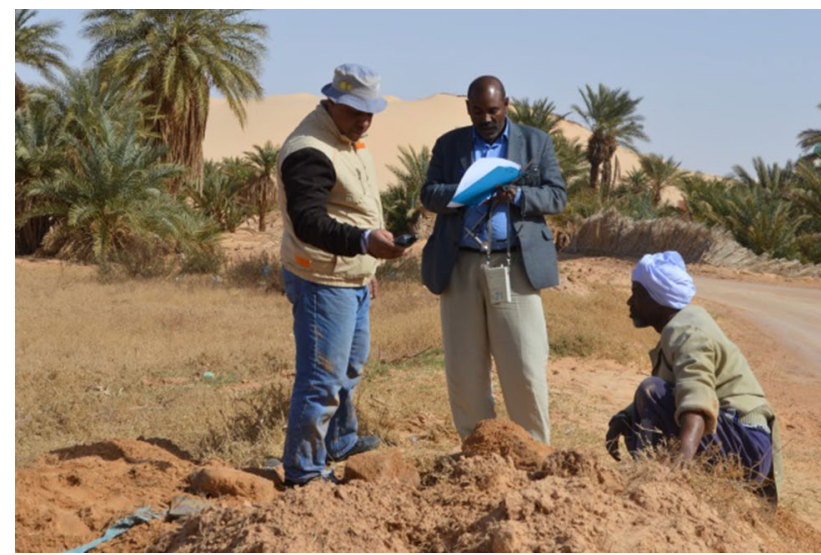

Fig. 5 January 16, 2018, investigations of the seguias of the foggara of Boukhzer. (photo. Authors 2018)

\section{Results and discussions}

\section{When the water of the foggara becomes a danger for the oasis of Bouda}

During the last 30 years, several foggaras have been drained as a result of drilling in the foggaras catchments of the oases of Touat, Gourara and Tidikelt. We can cite the example of the greatest foggara of Timimoun. This is the foggara of El Meghier which has deteriorated following the drawdown of the water table caused by drilling (Bensaada and Remini 2017; Remini and Achour 2008b). The foggaras of the small oasis of Bouda (Adrar) have not escaped this problem, since 5 boreholes intended for the drinking water supply of the commune of Bouda were realized during the period: 1987-1994, with a flow total discharge equal to $160 \mathrm{~L} / \mathrm{s}$, and a dynamic level that can reach $35 \mathrm{~m}$. The foggaras of the region of Bouda to the number of 22 extracted from the aquifer of Intercalary Continental, a flow of $86 \mathrm{~L} / \mathrm{s}$ according to the inventory carried out by the National Hydric Resources Agency in 1998. That is about $50 \%$ of the total pumped by the 5 boreholes. This flow of foggaras was revised downward in 2011, date of a second inventory carried out by the National Hydric Resources Agency; he went down to $70 \mathrm{~L} / \mathrm{s}$. For example, the distance between the Ben Draaou I well and the draining part of the Chiekh Ben Omar foggara gallery and the Ouled Gaenm foggara does not exceed $400 \mathrm{~m}$ (Fig. 6). This caused the water table to fold and consequently a decrease in foggara flow (Figs. 7, 8).

However, for reasons of water quality provided by the boreholes (salinity problem), the water resources services proceeded to stop these boreholes using the Bouda wellfield and replace them with two boreholes installed in the Oued Ghazal field $25 \mathrm{~km}$ west of Bouda (Fig. 9). The operation of the transfer of water from the Champs de Oued Ghazal took place in November 2015. However, nobody believed that from this date, the foggaras water floods the oasis. After a thirst that lasted more than 20 years, the foggaras are now slaughtered with water and continue to drive back huge volumes of water on all the axes that lead to the oasis. Everything was flooded; the flow never stopped and the foggaras can no longer control its water. The first consequence of this unusual flooding is definitely asphyxiation several palm trees (Fig. 10).

The water flows continuously since November 2015 causing so in the sebkha and the palm grove. Too much water in some areas of the palm grove caused soil salinization and the expansion of the sebkha to the profile of the palm grove (Fig. 11). Most importantly in this situation, the foggaras can no longer withstand the pressure of excess water since collapse of the aeration wells and landslides in the galleries were recorded in three foggaras (Fig. 12). Faced with this environmental disaster, farmers have only one urgent solution is to stop the flow before reaching the palm grove (Remini 2017). Logically, this imbalance of quantities of water cannot come from the stop of the drillings, since one returned to the initial state, that is to say before 1987, date of commissioning of the first drilling Bouda Bendraou 1. The foggaras have simply resumed their initial flow, about $140 \mathrm{~L} / \mathrm{s}$. Unfortunately, this is not the case, since foggaras could no longer drain such large quantities: the water flows more and more strongly. Faced with this environmental disaster, the oasis has only one urgent solution: Stop the flow before reaching the palm grove. Farmers made openings in several seguias to allow water to flow outside the foggara distribution network. The operation only delays the problem. In addition to this flood problem, which farmers are struggling to find a solution for, silting up foggaras is a longstanding problem that remains a daily struggle for farmers 


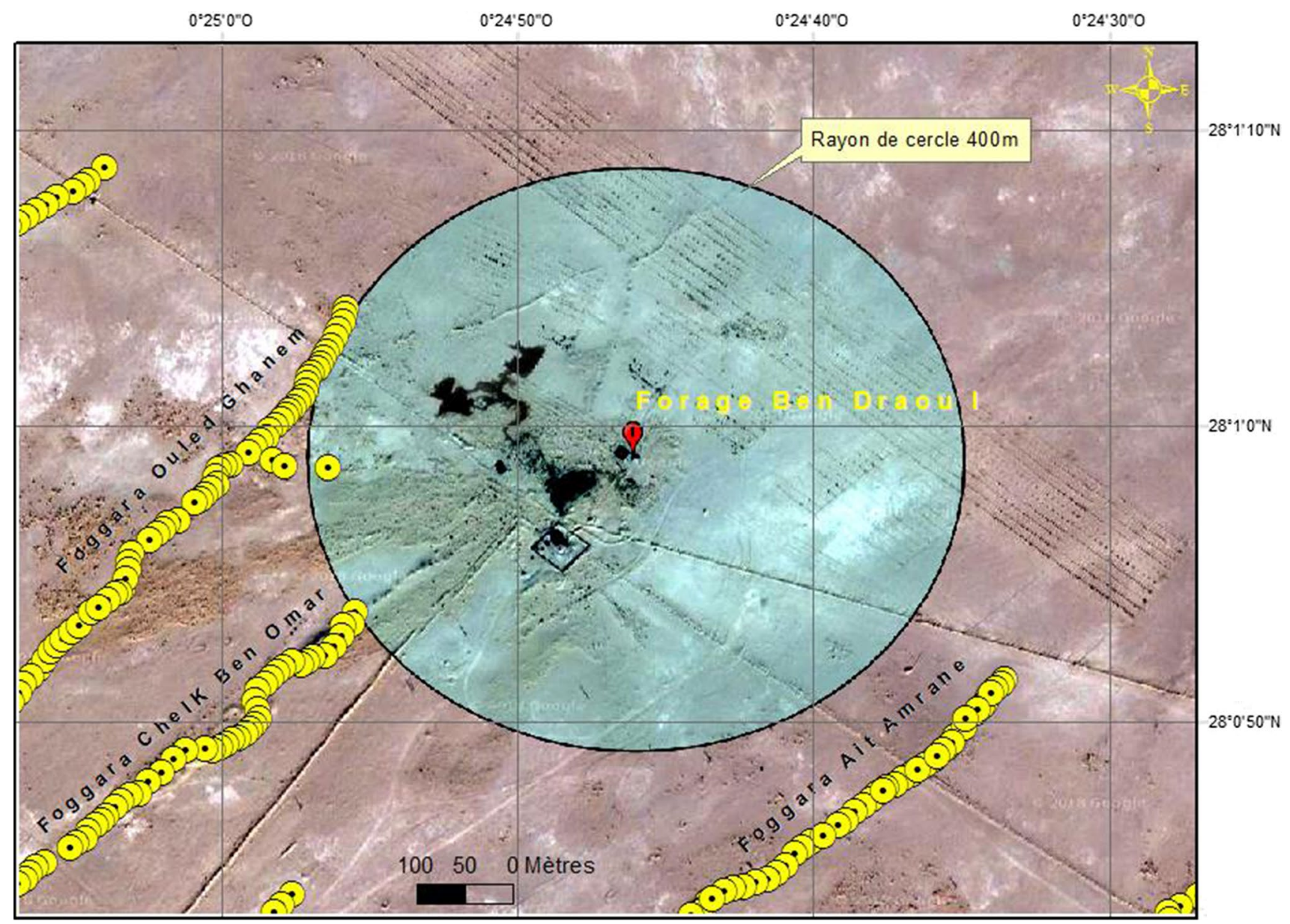

Fig. 6 Location of the Ben Draou I well in the catchment area of the foggaras. (own elaboration)

Fig. 7 Probable schema of a foggara of the oasis of Bouda before the putting into service of the boreholes (1987). (own elaboration)

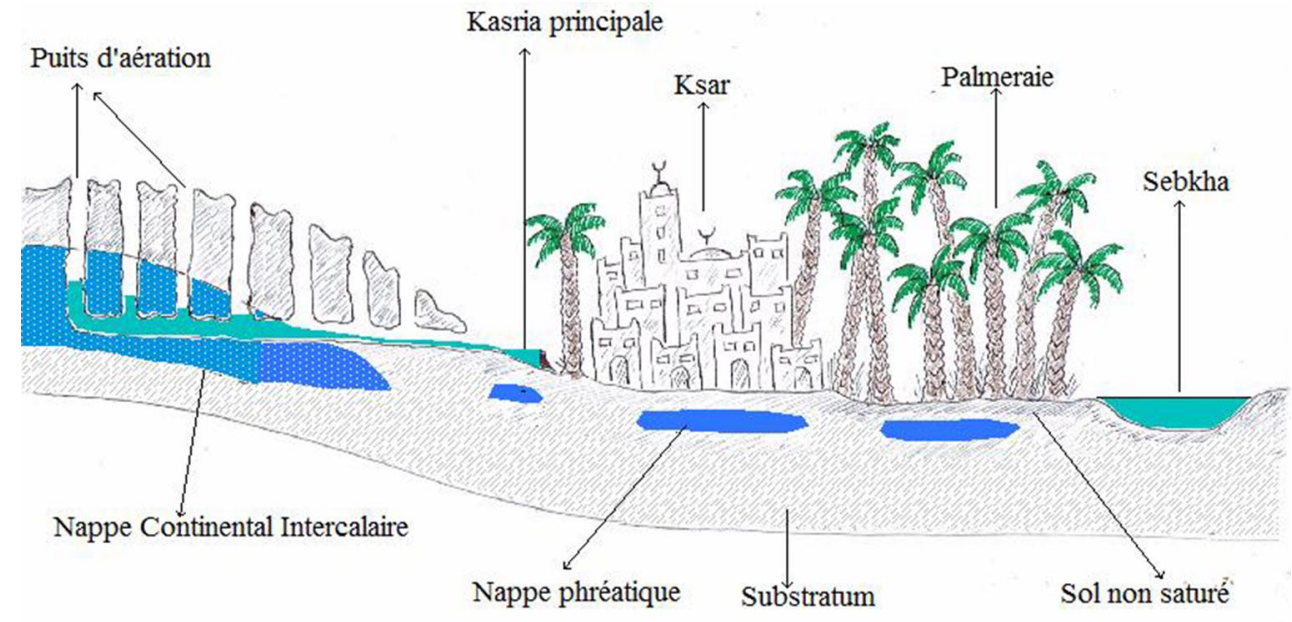


Fig. 8 Probable schema of a foggara of the oasis of Bouda after the drilling operation (1998). (own elaboration)

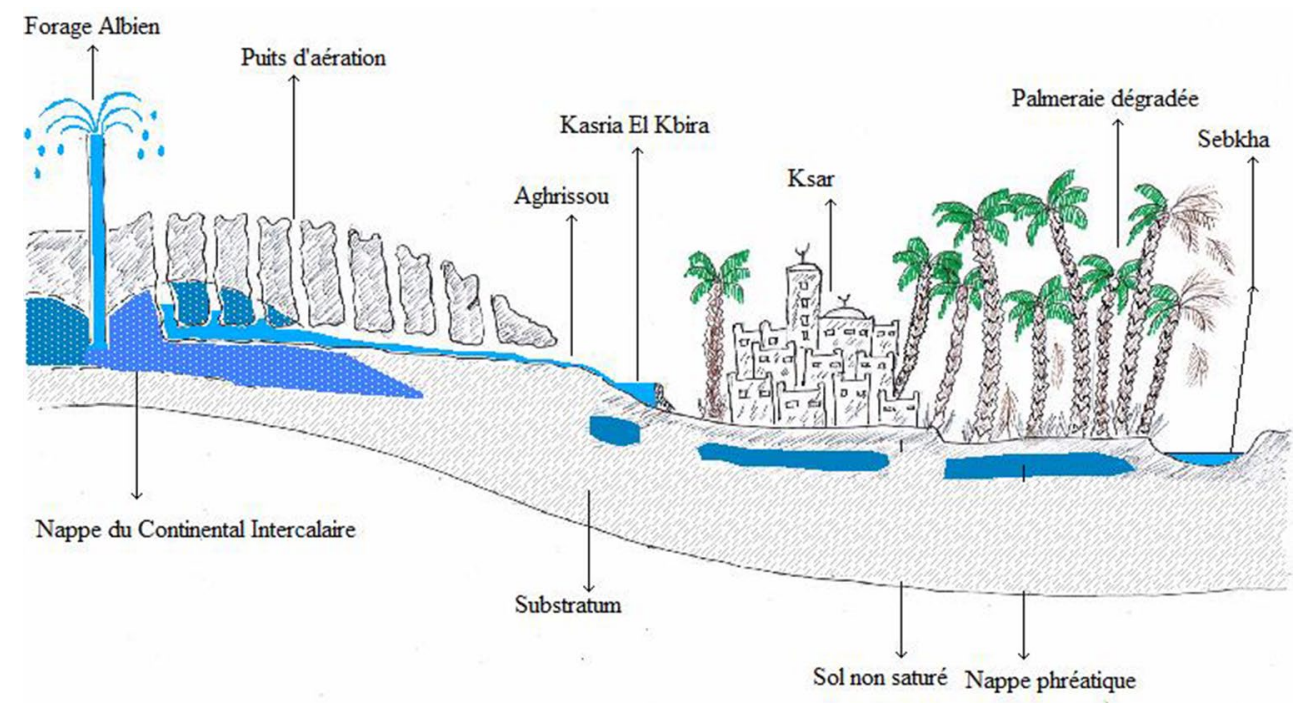

Sol non saturé Nappe phréatique

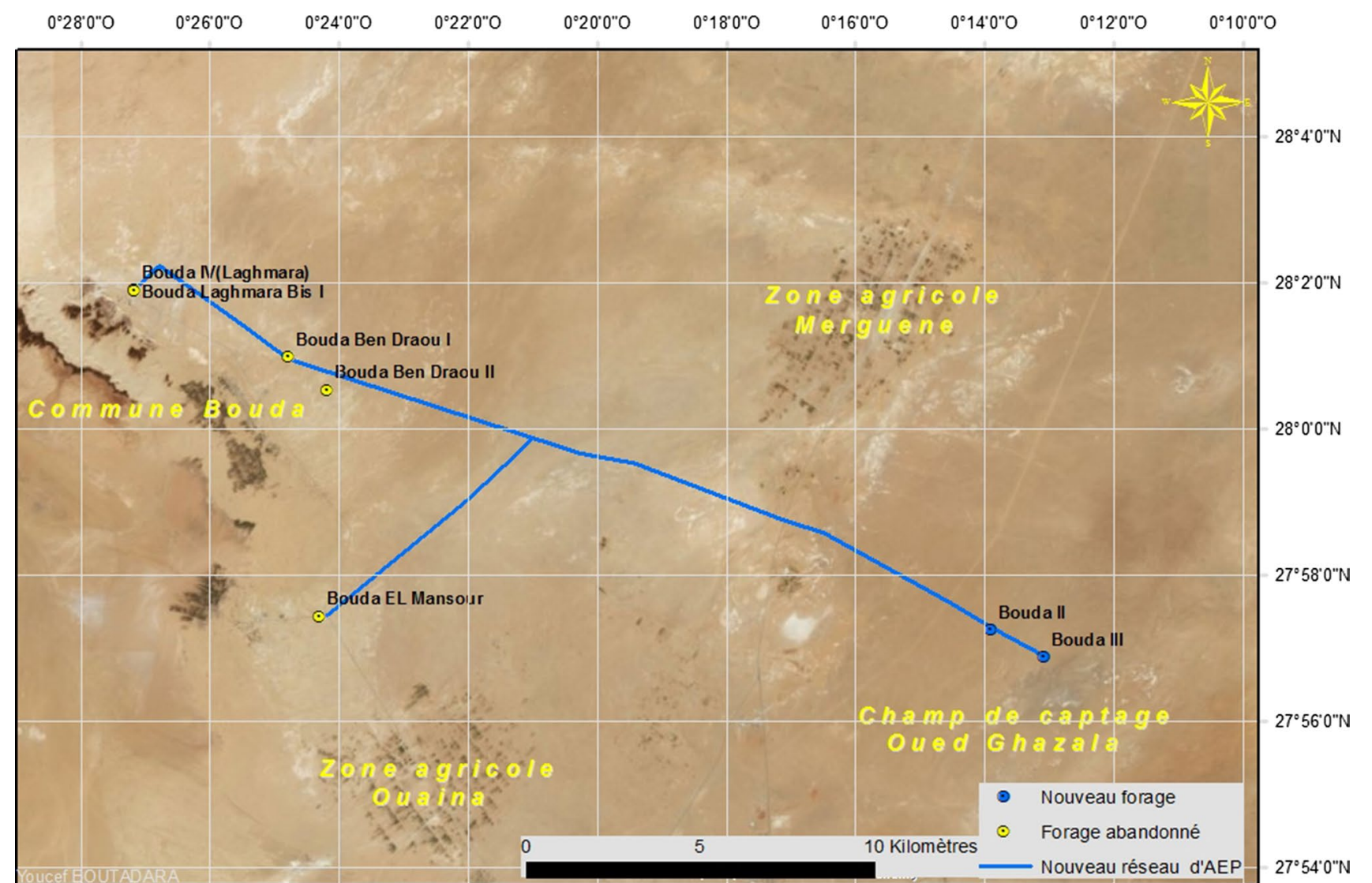

Fig. 9 Drilling situation and transfer of water to commune of Bouda. (own elaboration)

to carry out with rudimentary means to minimize damage (Figs. 13, 14).

In the commune of Bouda, 116 foggaras were dug during more than 10 centuries, or $5 \%$ of the total foggaras held by the wilaya of Adrar. Today, only 19 foggaras remain in service. We note on the figure a decrease in the flow of the foggaras from 1960 to 2011 for reasons of the absence of maintenance and the pumping in the catchment field of the 
Fig. 10 Probable schema of a foggara of the oasis of Bouda after the drilling stops (2016). (own elaboration)

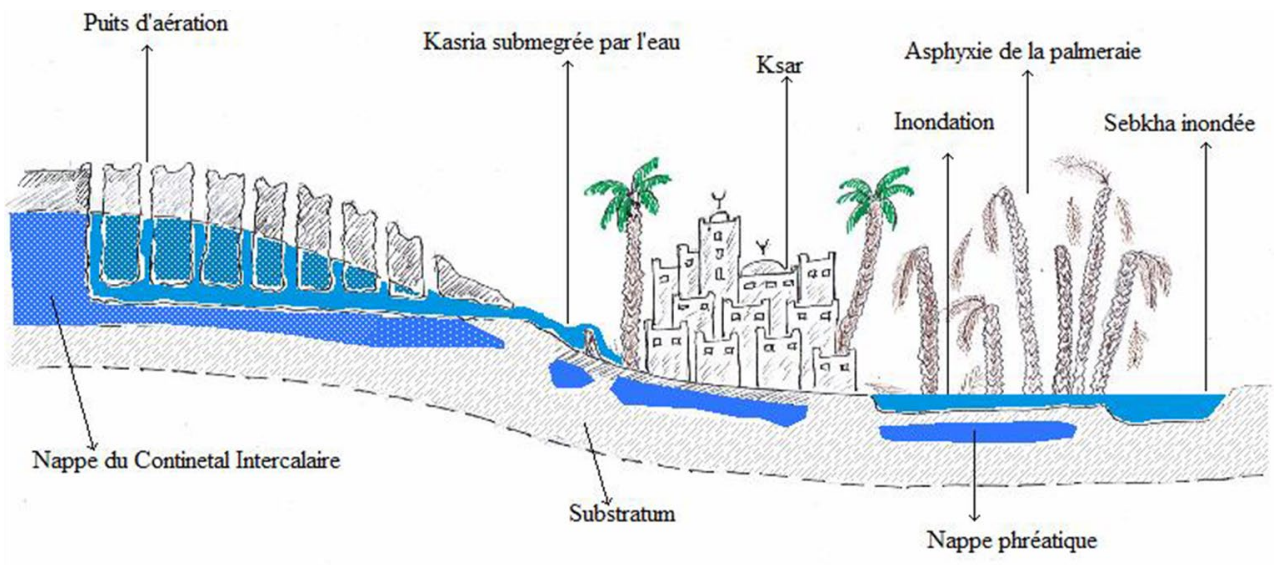

Fig. 11 A view of soil salinization in the oasis of Bouda. (photo. Authors 2018)

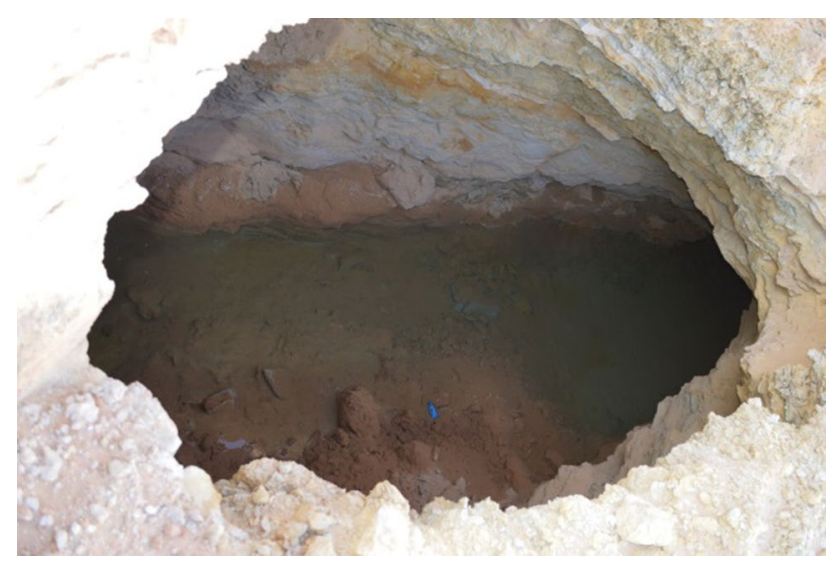

Fig. 12 Landslide in the gallery of the foggara of Mohamed Abdellah. (photo. Authors 2018)

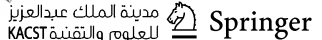

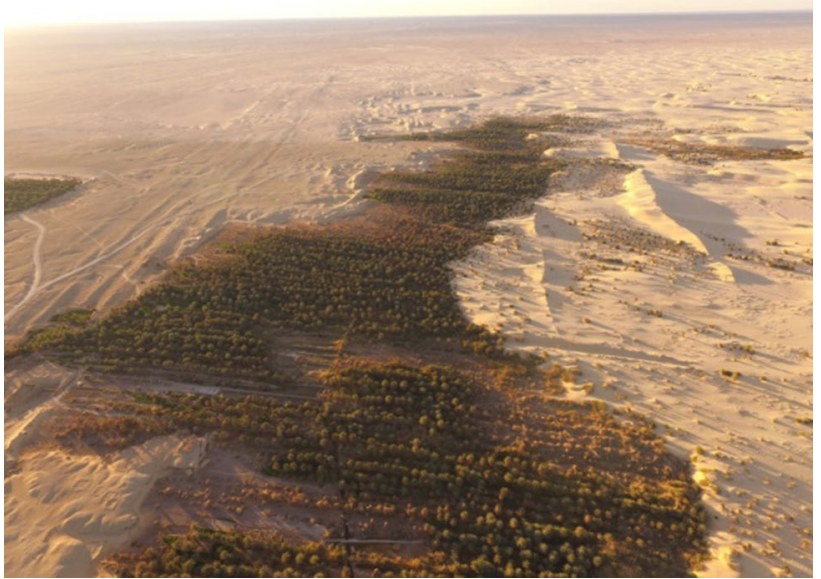

Fig. 13 An aerial view of the advance of the dunes on the palm grove of Bouda. (photo. Authors 2018)

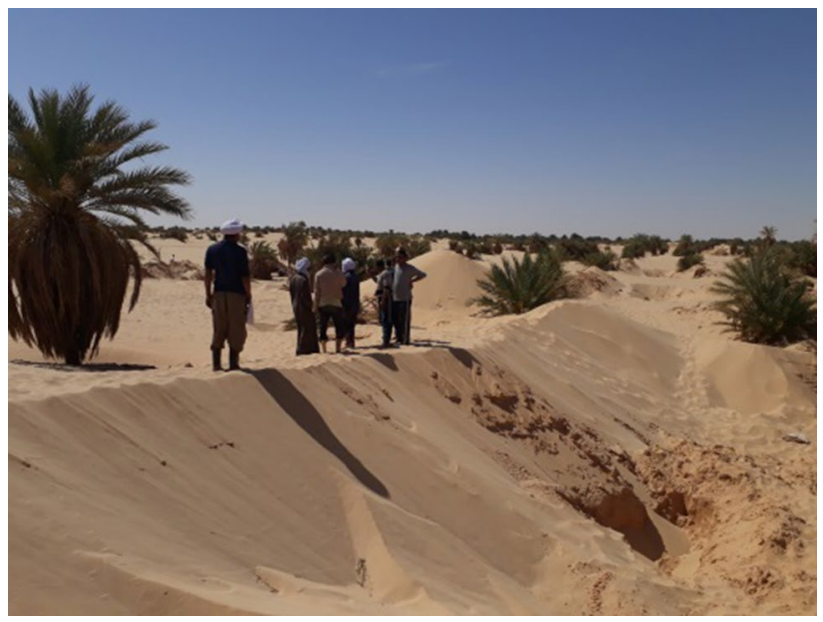

Fig. 14 A view of the silting of part of the palm grove of Bouda. (photo. Authors 2018) 


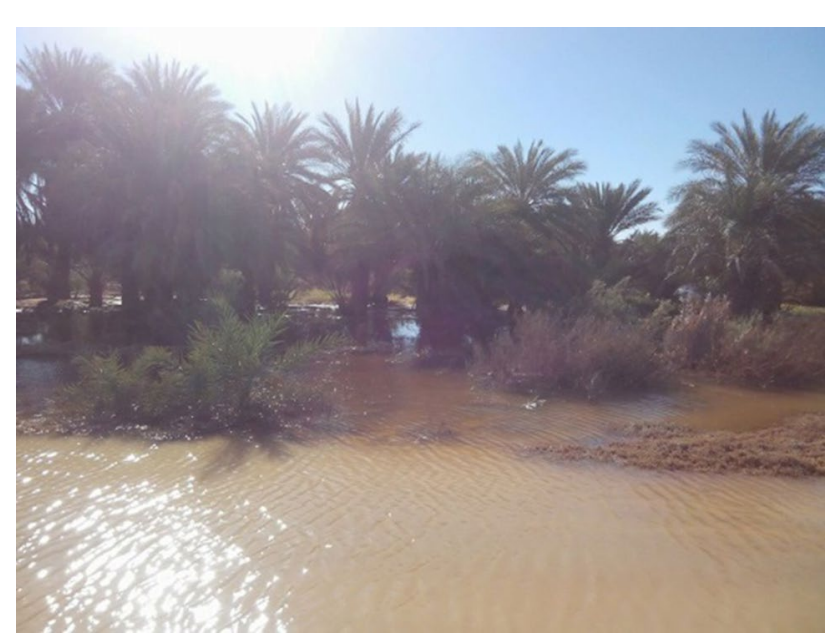

Fig. 15 Flooding of the Yellou palm grove. (photo. Authors 2018)

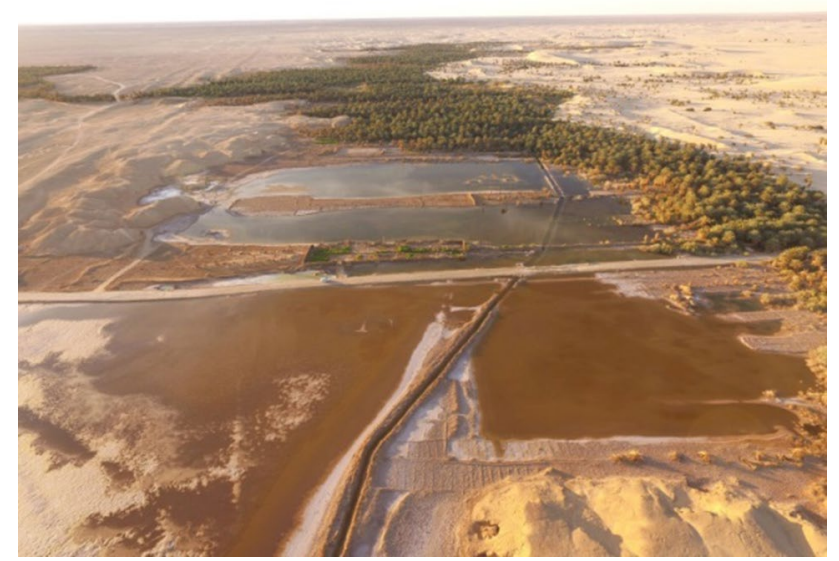

Fig. 16 Aerial view of the Kesibat Sebkha flood. (photo. Authors 2018)

foggaras. After the cessation of five holes located at the level of Bouda caused an imbalance of the flow in the set of foggaras. More than $50 \%$ of the foggaras (8 out of 19) saw their flows increased and far exceed those of 2011. For example, the flow rates of the Hadj Amar Kebir and Yellou foggaras increased by $50 \%$ compared to those of 2011 . The Igmou foggara flow increased by $100 \%$ compared to the last gauging (2011). This new situation caused by the return to the initial state (without pumping) was not predictable. Owners of foggaras have noticed the evolution of foggaras flow just after drilling stopped (in 2015), but after 1 year (in 2016), the situation has become worrying since it has moved from the phase of growth of the flow in the phase of rising water table in 2017. No one expected this excess water. No one can predict stopping and stabilizing this ascent (Figs. 15, 16, $17,18,19,20,21,22)$. Such a situation will certainly cause an acceleration of soil salinization and the asphyxiation of

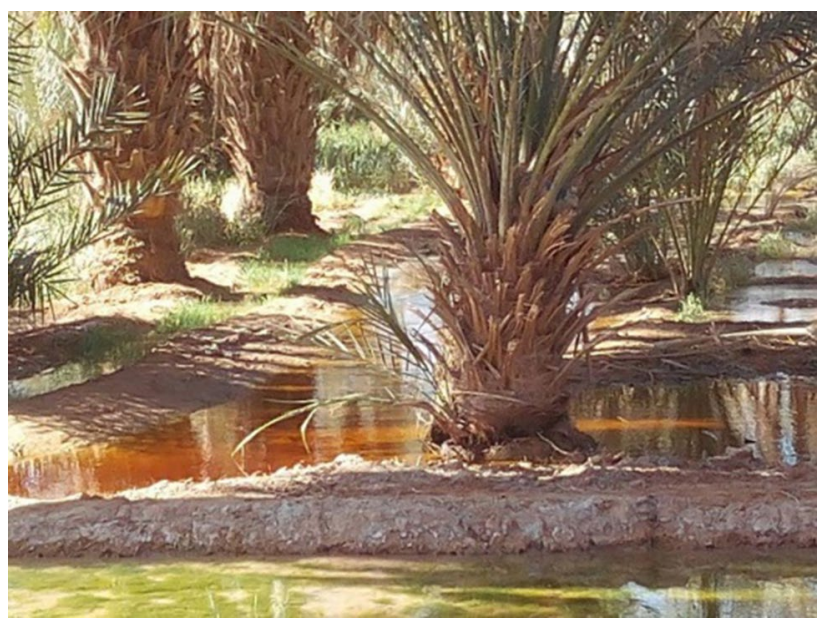

Fig. 17 Flooding of the Adouche palm groves. (photo. Authors 2018)

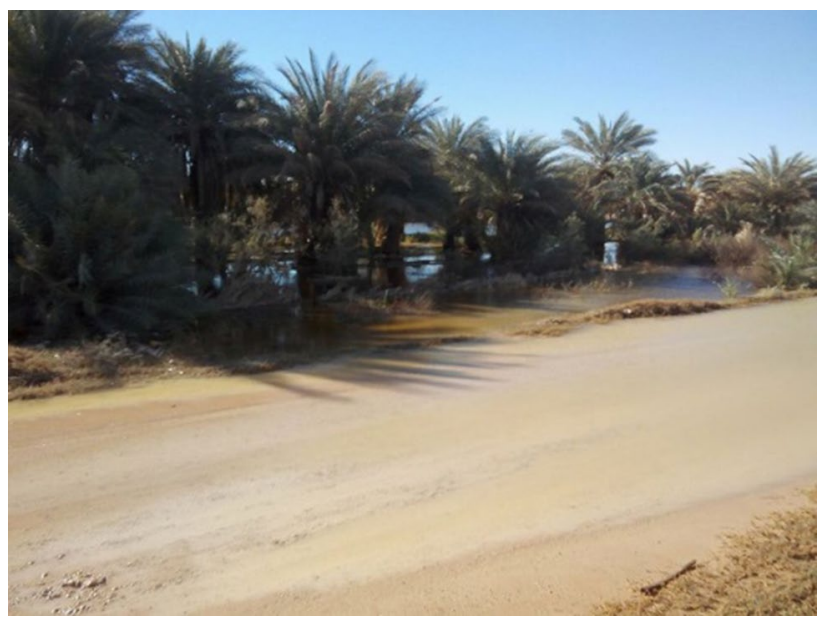

Fig. 18 Flooding of the palm grove of Hadj Amar Kebir. (photo. Authors 2018)

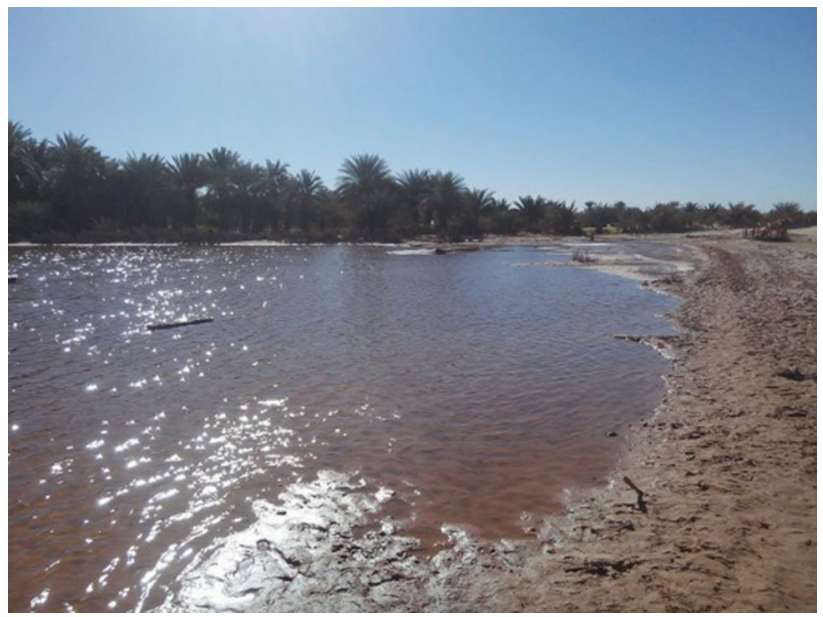

Fig. 19 Flooding of Kesibat palm groves. (photo. Authors 2018)

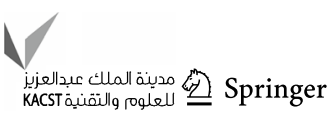




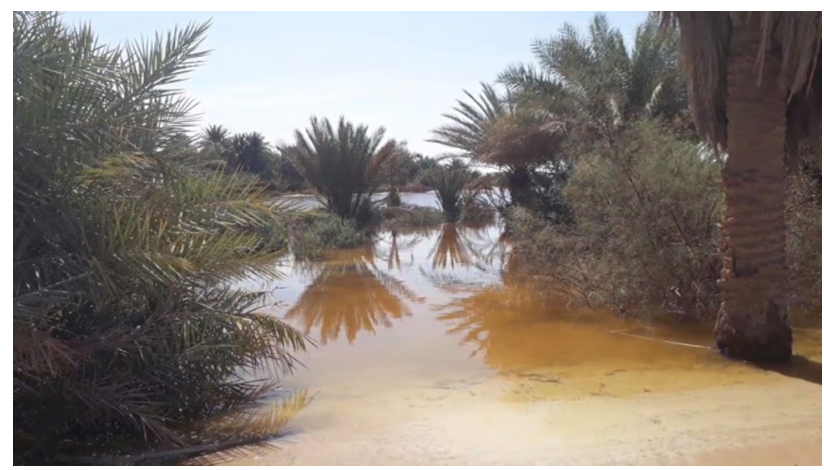

Fig. 20 Flooding of Igmou palm groves. (photo. Authors 2018)

several date palms. Taking advantage of this situation, the public services have launched a project of rehabilitation of 4 foggaras. They are Taier, El Hadjadj, Adouche Djedid and Mohamed Abdellah. An inventory and a map of all the foggaras in the town of Bouda have been drawn up with all the

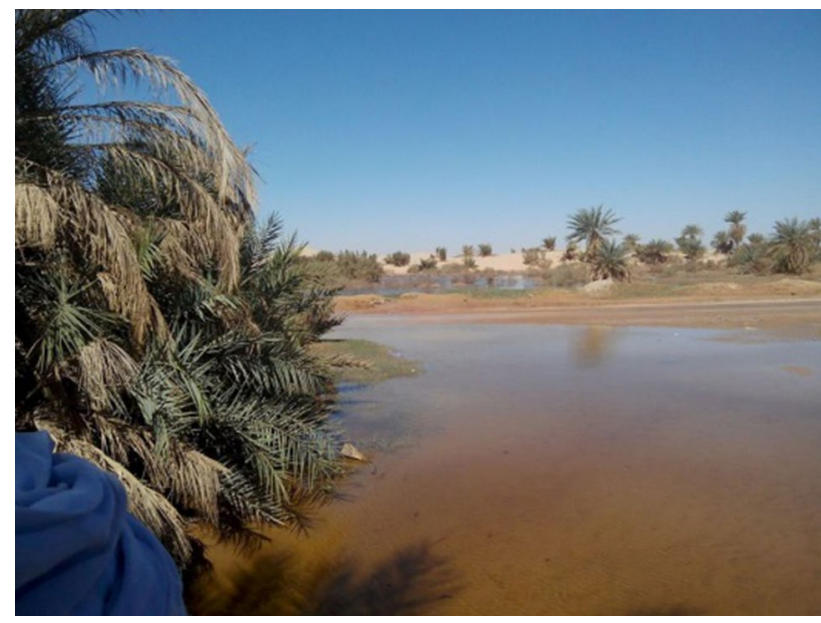

Fig. 21 Flooding of the Guemma palm grove. (photo. Authors 2018)

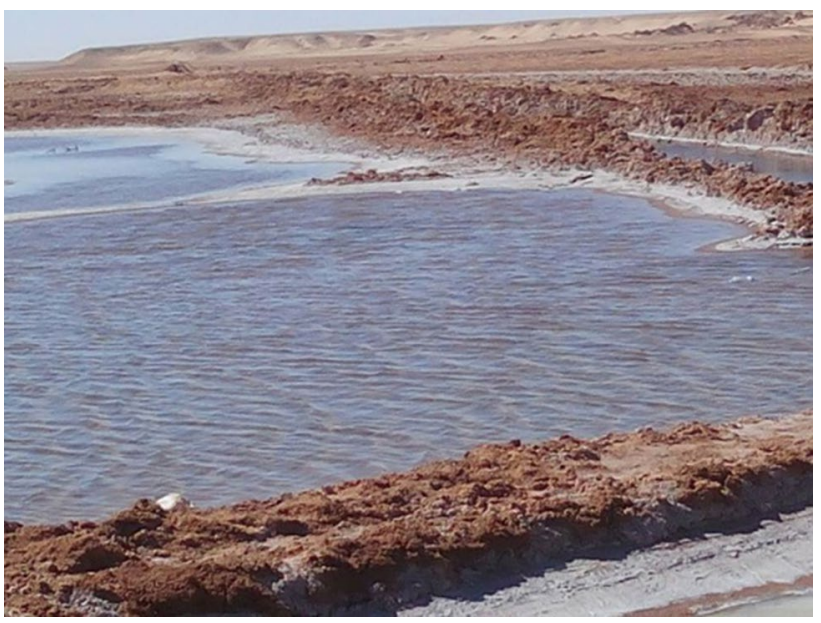

Fig. 22 Flooding of the Ben Draou Sebkha. (photo. Authors 2018)

remarks and observations recorded in the field (Table 1 and Fig. 23).

\section{Conclusion}

Who thought that after the stop of the drilling, the foggaras of Bouda wake up? The water that flows back into the galleries and the seguias of foggaras and even floods the palm grove. After the joy of the population to see their foggara gushing water (in 2016), but this holiday will not last long enough, since in the year 2018, the flow of foggaras of Bouda $(Q=77 \mathrm{~L} / \mathrm{s})$ far exceeded the one recorded in 2011 which was $68 \mathrm{~L} / \mathrm{s}$. However, flow is moving toward growth and no one can predict flow stabilization. This new situation characterized by floods begins to worry the Ksourian population. The water, after flooding the sebkha, part of the palm grove is under water. Today, the water flows in 19 foggaras out of $33 \mathrm{dug}$ since ten centuries. This phenomenon of 
Table 1 Flow of foggaras measured in 2018 in the oasis of Bouda

\begin{tabular}{|c|c|c|c|c|c|c|c|}
\hline No & Commune & Foggara & State of foggaras & $\begin{array}{l}2011 \text { flow (L/S) } \\
\text { (NAWR) }\end{array}$ & Flow 2018 (L/S) & Deference & Observation \\
\hline 1 & Bouda & Bakka Youcef & Sustainable & 0.80 & 0.00 & -0.80 & Silted \\
\hline 2 & Bouda & Igmou & Sustainable & 3.90 & 8.10 & +4.2 & \\
\hline 3 & Bouda & Aadjouch & Sustainable & 4.9 & 8.40 & +3.5 & \\
\hline 4 & Bouda & El Djedida & Sustainable & 4.90 & 1.60 & -3.30 & Silted \\
\hline 5 & Bouda & Yellou & Sustainable & 4.30 & 6.28 & +1.98 & \\
\hline 6 & Bouda & Hammou & Sustainable & 0.20 & 1.90 & +1.7 & \\
\hline 7 & Bouda & Taier & Sustainable & 1.40 & - & - & In rehabilitation \\
\hline 8 & Bouda & El Hadjadj & Sustainable & 2.60 & - & - & In rehabilitation \\
\hline 9 & Bouda & Hadj Amar Kebir & Sustainable & 10.00 & 16.10 & +6.1 & \\
\hline 10 & Bouda & Ahmed Seghir (El Bour) & Sustainable & 1.30 & 1.10 & -0.20 & Silted \\
\hline 11 & Bouda & Terbzou & Sustainable & 0.4 & 0.40 & 0.00 & \\
\hline 12 & Bouda & Adouche Djedid & Sustainable & 3.50 & - & - & In rehabilitation \\
\hline 13 & Bouda & Ait Amrane Abdouline & Sustainable & 4.20 & 1.40 & -2.80 & Silted \\
\hline 14 & Bouda & Tamlal & Sustainable & 14.30 & 14.50 & +0.2 & \\
\hline 15 & Bouda & Guermekar & Sustainable & 2.10 & 1.40 & -0.70 & Silted \\
\hline 16 & Bouda & Mohamed Abdellah & Sustainable & 0.80 & - & - & In rehabilitation \\
\hline 17 & Bouda & Guemma & Sustainable & 0.00 & 5.40 & +5.4 & \\
\hline 18 & Bouda & BOUZID & Sustainable & 8.50 & 8.50 & 0.00 & \\
\hline 19 & Bouda & Boukhzer & Sustainable & 0.00 & 2.60 & +2.6 & \\
\hline 20 & Bouda & Amnacer & Dried & 0 & 0 & 0 & \\
\hline 21 & Bouda & Suihla & Dried & 0 & 0 & 0 & \\
\hline 22 & Bouda & Figuiguira & Dried & 0 & 0 & 0 & \\
\hline 23 & Bouda & Tcosa & Dried & 0 & 0 & 0 & \\
\hline 24 & Bouda & Habbi & Dried & 0 & 0 & 0 & \\
\hline 25 & Bouda & Abankour & Dried & 0 & 0 & 0 & \\
\hline 26 & Bouda & Hachlef & Dried & 0 & 0 & 0 & \\
\hline 27 & Bouda & Mbirka & Dried & 0 & 0 & 0 & \\
\hline 28 & Bouda & Ouled Abderrahmane & Dried & 0 & 0 & 0 & \\
\hline 29 & Bouda & Sid El Arbi & Dried & 0 & 0 & 0 & \\
\hline 30 & Bouda & Siane & Dried & 0 & 0 & 0 & \\
\hline 31 & Bouda & Hadj Amar Seghir & Dried & 0 & 0 & 0 & \\
\hline 32 & Bouda & Sidi Said & Dried & 0 & 0 & 0 & \\
\hline 33 & Bouda & Yakbine & Dried & 0 & 0 & 0 & \\
\hline
\end{tabular}


Fig. 23 Situation of the foggaras of the oasis of Bouda. (own elaboration)

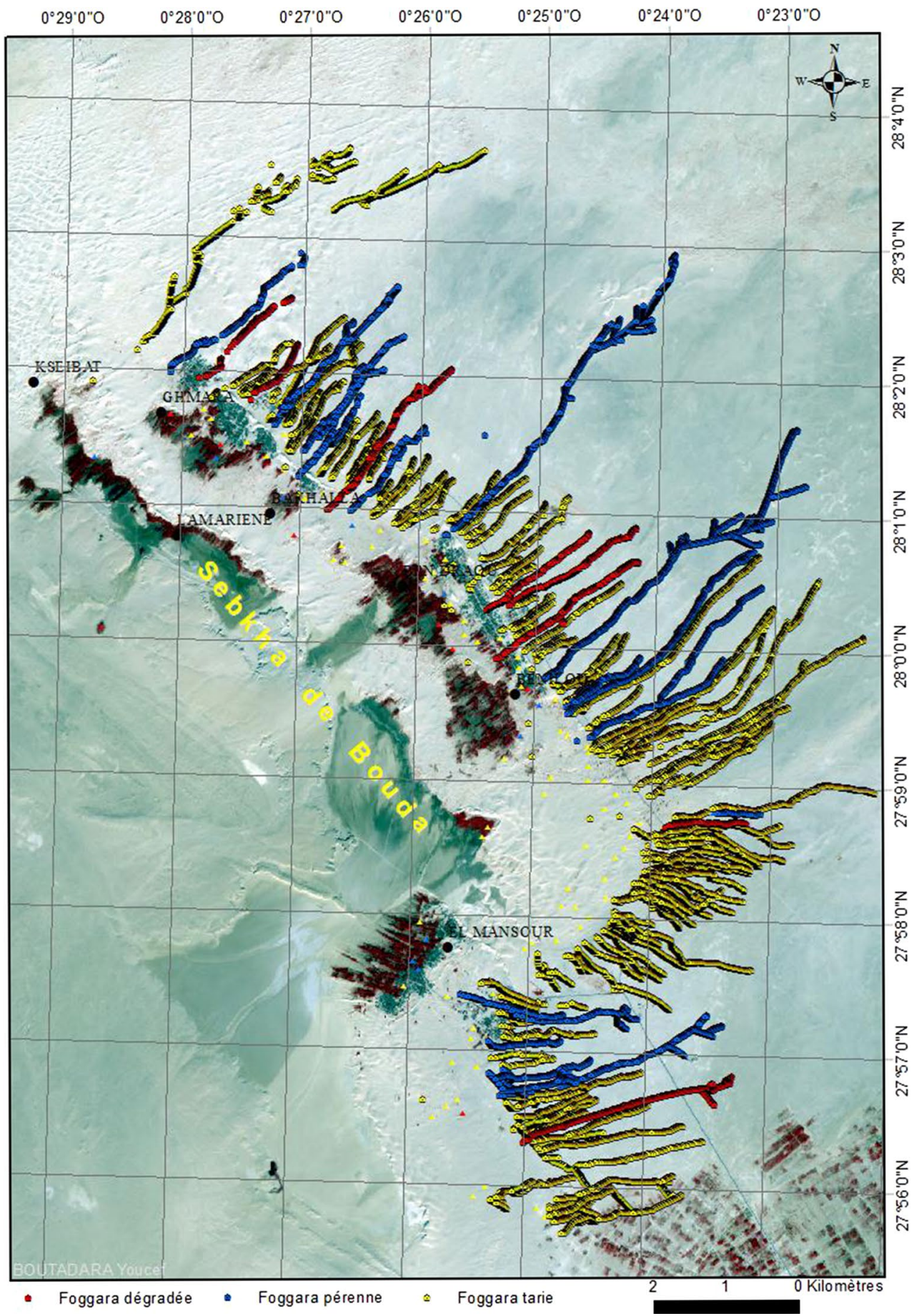

upwelling is a positive response. However, it must be taken seriously. This case can be generalized on all the foggaras who have a drying problem. The solution lies in the remoteness of the wells in the foggaras catchment area.

Acknowledgements Conducted a study on foggara in an arid region requires the help of several people. I take this opportunity to thank Messrs. Bourouba Brahim (National Hydric Resources Agency), Aichaou Salem Iwali (Guide and Expert of Bouda), Ouled Ben Said Salah (Observatory of the Foggaras), the owners of the foggara Hadj
Amer Lkbir and the Ksourian population of Bouda for the help that brought us for the preparation of this modest work.

Open Access This article is distributed under the terms of the Creative Commons Attribution 4.0 International License (http://creativeco mmons.org/licenses/by/4.0/), which permits unrestricted use, distribution, and reproduction in any medium, provided you give appropriate credit to the original author(s) and the source, provide a link to the Creative Commons license, and indicate if changes were made. 


\section{References}

Bensaada M, Remini B (2017) Water wells' exploitation and its impact on the drying up of foggaras. The case of the foggara of M'ghaer, Timimoun, District of Adrar, Algeria. Appl Water Sci 7(1):349359. https://doi.org/10.1007/s13201-014-0250-2

Goblot H (1963) In ancient Iran, the techniques of water and great story. Annales 18(3):499-520

Goblot H (1979) Qanats: a technique acquisition of water. Edition Mouton, Paris

Remini B (2017) The Tadmait foggara: without energy from basement water to soil surface. Larhyss J 32:301-325

Remini B, Achour B (2008a) Towards the disappearance of the biggest foggara of Algeria: the foggara of El Meghier. Revue Sécheresse (France) 19(3):217-221

Remini B, Achour B (2008b) The foggaras of the great western Erg Algerian. Larhyss J 7:21-37
Remini B, Achour B (2016) The water supply of oasis by Albian foggara: an irrigation system in degradation. Larhyss J 26:167-181

Remini B, Kechad R (2017) The socio-economic role of foggara in the oases of the Algerian Sahara. Afaq J Soc Sci Blida Univ 4(2):409-421

Remini B, Achour B, Albergel J (2011) Timimoun's foggara (Algeria): an heritage in danger. Arab J Geosci 4(3):495-506. https://doi. org/10.1007/s12517-010-0139-9

Remini B, Achour B, Kechad R (2014a) The collecting of groundwater by the qanats: a millennium technique decaying. Larhyss J 20:259-277

Remini B, Achour B, Kechad R (2014b) The foggara: a traditional system of irrigation in arid regions. Geosci Eng J LX(32):32-39

Publisher's Note Springer Nature remains neutral with regard to jurisdictional claims in published maps and institutional affiliations. 